\title{
Konstruktivisme Re-branding Balai Pengobatan Bunda Asri
}

\author{
Oleh: \\ Yuli Evadianti ${ }^{1} \&$ Siti Nur Jubaidah ${ }^{2}$ \\ (e-Mail: yulievadianti@gmail.com) \\ ${ }^{1}$ Dosen Ilmu Komunikasi Universitas Tulang Bawang Lampung, \\ ${ }^{2}$ Mahasiswa Ilmu Komunikasi Universitas Tulang Bawang Lampung.
}

\begin{abstract}
ABSTRAK
Peranan reputasi merupakan hal yang paling penting dalam membangun sebuah citra. Penurunan citra mengharuskan adanya tindakan yang diambil untuk mengantisipasi permasalahan. Penelitian ini merupakan penelitian dengan metode deskriptif kualitatif. Teori yang digunakan dalam penelitian ini adalah Situasional Crisis Communication Theory dan Image Restoration Theory. Tujuan penelitian ini adalah untuk mengetahui bagaimana mempertahankan reputasi dalam re- branding Balai Pengobatan Bunda Asri Natar dan untuk mengetahui apa saja yang dapat menurunkan reputasi Balai Pengobatan Bunda Asri. Sumber data yang digunakan dalam penelitian ini adalah data primer dan data sekunder. Berdasarkan analisis data yang dilakukan diperoleh kesimpulan bahwa dalam rangka Rebranding Balai Pengobatan Bunda Asri Natar pemulihan nama baik yang dibangun selama bertahun-tahun terlihat dari data jumlah customer atau pasien yang menigkat disetiap tahunnya.
\end{abstract}

Kata Kunci: Komunikasi, Re-Branding, Image, Komunikasi kesehatan

\section{PENDAHULUAN}

Eksistensi sebuah perusahaan sangat dipengaruhi oleh loyalitas publik sebagai khalayak sasarannya. Khalayak bisa royal terhadap suatu perusahaan jika pihak perusahaan mampu membangun dan memelihara reputasinya atau citra positif dimata khalayaknya. Reputasi yang baik perlu dibangun dengan usaha keras yang tentunya memerlukan waktu, tenaga, dan pikiran. Reputasi yang baik adalah suatu tanggung jawab besar Thomas (2011: 16541734).

Reputasi merupakan suatu nilai yang diberikan kepada individu, institusi atau negara. Reputasi tidak bisa diperoleh dalam waktu singkat karena harus dibangun bertahun- tahun untuk menghasilkan sesuatu yang bisa dinilai oleh publik. Reputasi juga baru bertahan dan sustainable apabila konsistennya perkataan dan perbuatan (Basya, dalam Basya dan Sati. 2006: 6).

Reputasi merupakan bagian dari sebuah citra, memperbaiki kembali sebuah reputasi tidaklah mudah. Peranan reputasi merupakan hal yang paling penting dalam membangun sebuah citra. Jika reputasinya rusak maka produk atau perusahaan akan mengalami kriris citra begitu pula yang dialami Balai Pengobatan Bunda Asri. Penurunan citra yang drastis mengharuskan adanya tindakan yang diambil untuk mengantisipasi permasalahan.

Dalam bidang kesehatan memiliki sebuah reputasi sangatlah penting memberikan kepercayaan terhadap publik. Balai Pengobatan Bunda Asri salah satu yang tergolong bereputasi dalam masyarakat sekitarnya. Karena jasa pelayanan yang diberikan kepada customer sebuah kenyamanan, respon yang baik, penanganan yang cepat dan tepat. penting dalam membangun sebuah citra. Jika reputasinya rusak maka produk atau perusahaan akan mengalami kriris citra begitu pula yang dialami Balai Pengobatan Bunda Asri. Penurunan citra yang drastis mengharuskan adanya tindakan yang diambil untuk mengantisipasi permasalahan. Balai Pengobatan Bunda Asri mengalami sebuah krisis citra yang sangat berpengaruh terhadap reputasi organisasi. Tersandungnya kasus asusila yang dilakukan oleh pemilik Balai 
Pengobatan Bunda Asri, sekaligus sebagai mantri yang memberikan jasa pelayanan kesehatan di Balai Pengobatan Bunda Asri menyebabkan reputasi yang terbangun selama empat tahun mengalami kemerosotan begitu saja. Krisis citra tersebut membuat Balai Pengobatan yang bereputasi baik dimata masyarakat menjadi bereputasi buruk sehingga sangat mempengaruhi masyarakat sekitar. Sebuah krisis dapat memberikan dampak yang begitu besar serta jangka waktu yang sangat lama dalam memulihkan sebuah reputasi.

Re-branding merupakan upaya yang dilakukan oleh perusahaan untuk merubah citra produk atau perusahaan dengan penggantian atau keseluruhan merek. Rebranding terdiri dari dua kata yakni "re" yang berarti melakukan hal untuk kedua kalinya atau pengulangan dan "brand" yang berarti citra merek. Sehingga dapat dikatakan Re-branding sebagai peraktek membangun sebuah nama baru lagi yang mewakili posisi yang berbeda dibenak pemegang kepentingan dan sebuah identitas khusus. Berdasarkan latar belakang di atas, maka peneliti tertarik untuk membuat judul penelitian Konstruktivisme Re-branding Balai Pengobatan Bunda Asri.

Adapun rumusan masalah yang diteliti adalah Bagaimana Balai Pengobatan Bunda Asri Natar melakukan Re-branding dengan memulihkan reputasi mereka?

Situational Crisis Communication Theory (SCCT) Timothy W. Coombs dan Holladay S.J, Teori SCC ini mengantisipasi reaksi public terhadap krisis yang dapat mengancam reputasi organisasi. Teori kedua Image Restoration Theory William Benoit (Teori Restorasi Citra) juga di jelaskan, sebagai cara memahami situasi krisis citra pribadi atau organisasi, maupun sebagai langkah taktis untuk memulihkannya.

\section{METODE PENELITIAN}

Dalam penelitian yang telah dilakukan, peneliti menggunakan metode penelitian kualitatif. penelitian kualitatif dalam penelitian yang telah dilakukan adalah bersifat deskriptif. deskriptif artinya data yang dikumpulkan adalah berupa katakata, gambar dan bukan angka- angka (moleong 2010 : 11).

Metode analisis data deskriptif kualitatif dalam penelitian ini berguna untuk mengembangkan teori yang telah dibangun dari data yang didapatkan dilapangan. metode kualitatif pada tahap awalnya peneliti melakukan penjelajahan seperti turun langsung ke lapangan, kemudian peneliti melakukan pengumpulan data sampai mendalam atau lebih detail, mulai dari observasi, wawancara, dokumentasi hingga penyusunan laporan.

Penelitian ini akan diambil data serta penjelasan mengenai (re-branding) sebagai pemulihan citra balai pengobatan bunda asri secara umumnya. harapannya penulis dapat menemukan jawabanjawaban permasalahan yang ada dalam penelitian ini. penulis berinteraksi langsung dengan (customer) maupun mengetahui kondisi sebenarnya yang terjadi. penulis turun kelapangan dan berada dilokasi penelitian untuk memperoleh data. penulis bahkan melakukan pengamatan dengan melakukan pertemuan dengan customer yang merupakan subjek penelitian ataupun informan hingga berhari-hari. sumber data yang diperoleh melalui sumber-sumber, yaitu : teknik observasi, wawancara, dokumentasi. teknik analisis data dalam penelitian ini dengan menggunakan metode observasi turun langsung ke tempat atau objek penelitian yang sedang diteliti.

Proses analisa data kualitatif dilakukan dengan tahap sebagai berikut: 1.reduksi data merupakan proses pemilihan, pemusatan perhatian pada penyederhanaan, mengabstrakkan, dan transformasi data kasar yang muncul dari catatan. 2.catatan tertulis di lapangan, dimana setelah peneliti memperoleh data, harus lebih dulu dikaji kelayakannya dengan memilih data mana yang benar-benar dibutuhkan dalam 
penelitian ini. 3. penyajian data dibatasi sebagai sekumpulan informasi tersusun yang disesuaikan dan diklarifikasi untuk mempermudah peneliti dan menguasai data dan tidak terbenam dalam setumpuk data. 4 . verifikasi (menarik kesimpulan) yaitu kesimpulan selama penelitian berlangsung makna-makna yang muncul dari data yang diuji kebenarannya, kekokohannya dan kecocokannya sehingga diperoleh kesimpulan yang jelas kebenaran dan kegunaannya (Bogdan \& Biklen dalam Moleong, 2010 : 179).

\section{HASIL PENELITIAN}

Pemulihan kembali sebuah reputasi yang sudah terbangun sangatlah membutuhkan proses yang cukup lama. Balai Pengobatan Bunda Asri. melakukan berbagai upaya- upaya pemulihan nama baik atau biasa disebut re-branding. Strategi menjadi tolok ukur keberhasilan dalam mengembalikan sebuah reputasi dan nama baik Balai Pengobatan Bunda Asri. Pengelolaan isu dan krisis yang harus ditangani dengan cepat dan tepat sehingga menunjukkan pemulihan secara signifikan. Adapun hal-hal yang dilakukan oleh Balai Pengobatan Bunda Asri dalam rangka pemulihan nama baiknya dengan membuat strategi komunikasi yang tepat serta membuat program perencanaan kembali. Habil S.K.M, M.Kes memaparkan program di Balai Pengobatan Bunda Asri ini khusus untuk berfokus pada pengembangan sebagai pusat sunat modern untuk sunat smart klamp di Lampung. Rencana kedepan akan dibangun gedung dan mencari lokasi yang lebih arah kedepan sehingga lebih memudahkan akses jalan dan lokasi ini khusus untuk sunat modern di Lampung tegasnya. Tidak hanya akan bekerjasama dengan BPJS, namun sudah ada program yang dijalani selama Balai Pengobatan ini terbangun.

Sunat modern merupakan salah satu strategi dalam memulihkan reputasinya kembali, sunat ini biasanya gratis yang diadakan untuk kegiatan amal yaitu sunatan masal untuk masyarakat sekitar. Masih banyak hal-hal yang dilakukan Balai Pengobatan Bunda Asri dalam rangka pemulihan nama baiknya, Seperti pengakuan Okta Via Ningsih (24 Tahun):

"Ada.. yah salah satunya yang tadi yah.. lebih melakukan pendekatan kepada pasiennya, jika di mintai pertolongan siap membantu layanan homecare contohnya pasien diabetes, pasien luka, atau sudah tua dan memang yang tidak bisa berjalan atau bangun lagi. Ada juga nih misalnya kaya suntik faksin, rubella, campak kita bantu dan gratiskan. misalkan ada pasien yah maaf ada yang kurang mampu istilahnya kami bebaskan biaya, seadanya pun seikhlasnya kami terima, dan kami ada lagi strategi kalau di sini di adakan sunatan masal, tentunya di hari-hari anak-anak libur sekolah, itu kita adakan sunatan masal. Itu kami adakan, misalkan gk terlalu banyak yang penting untuk amalnya aja. Kami juga di sini memiliki daya tarik yang tidak di miliki oleh klinik lain yaitu sunat smart clamp, khitan jaman now, sebenarnya sama aja berkhitan jaman dulu, tapi sekarang lebih praktis tidak di jahit tanpa di suntik itu aja. Dia lebih canggihnya lah. Kalau untuk di lampung baru ada di sini, di sini dokter sebagai mentornya lah, jadi sudah lama. Di adakan seminar juga di luar kota. Lalu memang di adakan distributor di sini, jadi dokter ke dokter di ajarkan lama kelamaan bakal tau. Yang berminat ini ramai, apa lagi khusus anak-anak beragama islam aja yah. Bagaimana sih anak-anak ini tidak merasakan sakit lagi, gk di suntik, gk di jahit, gk ribet, dan gk perlu lagi dia kontrol lagi ke Balai Pengobatan,nahh mangkanya ini yang jadi daya tarik di sini, namanya khitan smart clamp, khitan jaman now." (Wawancara dengan Okta Via Ningsih pada tanggal 17 Januari 2019)

Dari hasil analisis wawancara Okta Via Ningsih (24 Tahun) menjelaskan secara detail apa saja yang menjadi strategi Balai Pengobatan Bunda Asri selama ini:Pertama, melakukan pendekatan kepada pasien atau customernya seperti adanya pertolongan 
pertama gawat darurat siap membantu pelayanan homecare untuk pasien diabetes, pasien luka, dan memang pasien tua yang sudah tidak bisa berjalan atau bangun lagi. Kedua, adanya penggeratisan suntik faksin rubella, difteri, dan campak.

Balai Pengobatan Bunda Asri juga memberikan bantuan jikalau ada pasien atau customer yang kurang mampu dan sangat membutuhkan maka akan dibebaskan biaya, namun jika pasien yang kurang mampu ingin membayar seikhlasnya pun akan tetap diterima oleh pihak Balai Pengobatan. Hal ini sering dilakukan dengan adanya harapan kedepan menjadi ladang amal untuk Balai Pengobatan Bunda Asri serta memperbaiki dan mengembalikan citra yang beberapa tahun mengalami penurunan. Ketiga, mengadakan sunat masal dihari anak-anak libur sekolah, beliau menjelaskan bahwa walaupun yang ikut serta dalam berpartisipasi jumlahnya tidak terlalu banyak, namun beliau mengharapkan dengan adanya kegiatan sunat masal ini masyarakat mengetahui bahwa Balai Pengobatan Bunda Asri melakukan kegiatan amal. Serta yang terpenting keikhlasan dalam melakukan kegiatan ini, lalu mendapatkan balasan pahala tegasnya.

Beliau memaparkan juga daya tarik Balai Pengobatan Bunda Asri yang tidak dimiliki oleh Balai Pengobatan lain iyalah program sunat smart klamp, khitan jaman now, sebenarnya sunat ini sama dengan sunat menggunakan metode lama namun anak-anak sekarang yang tanpa kita sadari lebih menyukai hal praktis sunat ini lah solusinya. Canggihnya sunat smart klamp lebih praktis, tidak dijahit, tanpa disuntik, tidak sakit, tidak ribet, dan tidak perlu datang untuk kontrol kembali ke Balai Pengobatan. Beliau menjelaskan bahwa kota Lampung merupakan kota pertama dan sunat ini baru ada di Balai Pengobatan Bunda Asri serta Dokternya sendiri pun sebagai trainer yang mengadakan seminarseminar diluar kota, sunat dengan metode ini sudah banyak orang ketahui keberadaannya diluar kota Lampung maka dari itu sunat modern ini menjadi daya tarik tersendiri dimasyarakat sekitar Balai Pengobatan Bunda Asri.

Smart klamp merupakan metode dan teknik sunatan yang diperkenalkan sejak tahun 2001 di Jerman. Penemu dari metode sunat modern ini adalah dr. Harrie van Baars yang mana saat ini Smartklamp telah dikembangkan dan diproduksi di Malaysia.

Keuntungan menggunakan alat ini diantaranya adalah : melindungi kepala penis saat disunat, pendarahan sedikit sehingga mengurangi risiko infeksi dan tidak memerlukan antibiotik, alat ini mudah digunakan, mencegah cedera pada saat proses sunatan, proses sunat cepat hanya 7 menit, dengan mekanisme penutupan "klik" maka tidak perlu lagi jahitan, hasil yang lebih baik dan simetris, aman bagi pasien diabetes, hemofilia, autis atau hiperaktif. Strategi menjadi tolok ukur keberhasilan dalam mengembalikan sebuah reputasi dan nama baik Balai Pengobatan Bunda Asri. Pengelolaan isu dan krisis yang harus ditangani dengan cepat dan tepat sehingga menunjukkan pemulihan secara signifikan. Adapun pemulihan tersebut dapat terlihat dari data pasien naik dan menurunnya jumlah pasien atau customer yang datang ke Balai Pengobatan Bunda Asri sebagai berikut :

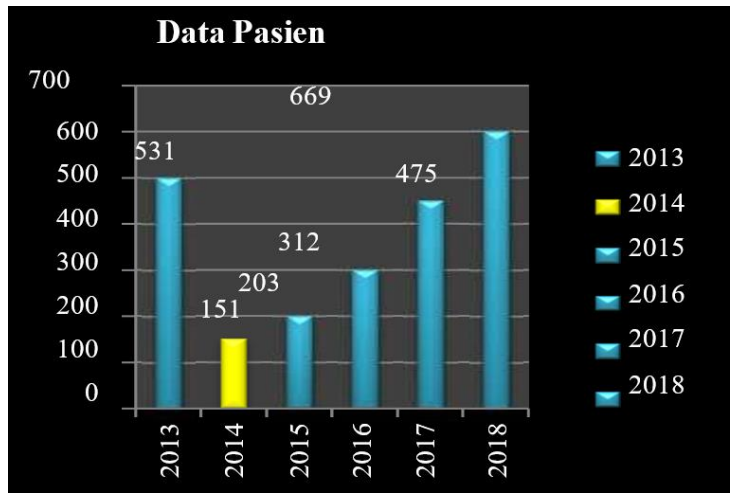

Sumber: Balai Pengobatan Bunda Asri, data dioiah Oiktober 2018

Dilihat dari diagram diatas diterangkan bahwa pasien atau customer awal Tahun 
2013 sebelum terjadinya kasus asusila yang dilakukan oleh pemilik Balai Pengobatan Bunda Asri memiliki jumlah pasien 531 orang pertahun. Setelah terjadinya kasus asusila terlihat pada Tahun 2014 mengindikasi adanya permasalahan kemudian mengalami keanjlokan jumlah pasien yang sangat signifikan yaitu kisaran jumlah pasien menjadi

151 orang pertahun. Kemudian terlihat setelah tahun pertama mengalami krisis citra jumlah pasien menunjukkan peningkatan walaupun persentasenya sebesar $1 \%$ pada Tahun 2015 berjumlah 203 orang pertahun. Tahun 2016 mengalami kenaikan jumlah pasien sedikit demi sedikit yaitu kisaran 312 orang pertahun. Pada diagram diatas Balai Pengobatan Bunda Asri terlihat mengalami progres kenaikkan pasien yang cepat, Tahun 2017 menunjukkan jumlah pasien 475 orang pertahun yang artinya upaya- upaya dalam memulihkan nama baiknya mulai membuahkan hasil positif. Konstruktivisme re-branding Balai Pengobatan Bunda Asri merupakan upaya yang selama bertahuntahun dilakukan dalam memulihkan nama baiknya dimata masyarakat sekitar, diagram diatas menjelaskan adanya keberhasilan dalam menangani krisis citra dan membuktikan bahwa lonjakkan itu secara signifikan terjadi yaitu sejumlah 669 orang pertahun.

\section{SIMPULAN}

Dalam rangka pemulihan reputasi yang dilakukan Balai Pengobatan Bunda Asri dengan membangun program-program yang tepat yaitu memberikan pelayanan ekstra (Home Care), pemberian obatobatan yang berkualitas, tarif berobat murah bahkan bagi kaum duafa (tidak mampu) digratiskan, bekerja sama dengan Badan Penyelenggara Jaminan Sosial (BPJS), serta mengadakan kegiatan amal dengan Metode Sunat Smart Klamp (Sunathrone).

Upaya yang dibuktikan Balai
Pengobatan Bunda Asri Natar mendapatkan respon yang positif dari masyarakat sekitar. Nama baik yang dibangun selama bertahuntahun melalui setrategi serta penanganan yang tepat dapat menyelesaikan semua permasalahan yang terjadi.

Hasil dari pulihnya citra kembali semakin terlihat dari data dilapangan dengan memaparkan jumlah customer atau pasien yang datang ke Balai Pengobatan Bunda Asri Natar meningkat pesat disetiap tahunnya.

\section{DAFTAR PUSTAKA}

Cangara Hafied. (2014). Pengantar Ilmu Komunikasi. PT Raja Grafindo Persada. Jakarta

Creswell, John W. (2015). Penelitian Kualitatif \& Desain Riset; Edisi Ketiga Yogyakarta : Cetakan Pustaka Pelajar

Effendi, Onong Uchjana. (2000). Ilmu Teori \& Filsafat Komunikasi. PT Citra AdityaBakti, Bandung

Mukhtar. (2013). Metode Penelitian Deskriftif Kualitatif. Jakarta : GP Press Group

Nova Firsan. (2011). Crisis Public Relations, PT Raja Grafindo Persada, Jakarta

\section{Jurnal :}

Masduki. 2014. Strategi Pemulihan Citra Partai Politik: Kasus Partai Demokrat. UNISIA, Vol. XXXVI/ No. 8/ 1 Juli 2014, hal 1-10 (21 Agustus 2018)

Roro Retno Wulan. 2017. Strategi ReBranding Zora Radio. PRofesi Humas: Jurnal Ilmiah Ilmu Hubungan Masyarakat, Volume 2/No. 1/ 7 Agustus 2017, hal 1-12 (7 September 2018)

\section{Skripsi \& Jurnal}

Zakaria, Zurya Hikmah. 2016. Strategi Komunikasi Program Corporate Social 
Responbility PT Pertamina (Persero) Terminal BBM Kendari dalam Meningkatkan Citra Perusahaan. Skripsi: FISIP. Universitas Halu Oleo: Kendari.

Inayah, Nurul. 2017. Strategi Komunikasi Corporate Social Responsibility dalam meningkatkan citra perusahaan di PT. Cirebon Electric Power. Jurnal Ilmu Komunikasi. Volume 5 No. 2 